\title{
Austroeupatorium inulifolium invasion alters litter dynamics in Cymbopogon nardus-dominated man-made grasslands
}

\author{
I.P.K. Piyasinghe ${ }^{1,2^{*}}$, Jagath Gunatilake ${ }^{3}$ and H.M.S.P. Madawala ${ }^{1}$ \\ ${ }^{I}$ Department of Botany, Faculty of Science, University of Peradeniya, Peradeniya. \\ ${ }^{2}$ Postgraduate Institute of Science, Peradeniya. \\ ${ }^{3}$ Department of Geology, Faculty of Science, University of Peradeniya, Peradeniya.
}

Submitted: 11 December 2017; Revised: 19 June 2018; Accepted: 28 September 2018

\begin{abstract}
Austroeupatorium inulifolium has become a noxious invader, expanding its populations in a variety of habitats in the mid-country of Sri Lanka. Highly degraded man-made grasslands dominated by Cymbopogon nardus in the Knuckles Conservation Area (KCA) have shown a high vulnerability for A. inulifolium spread. The present study was aimed at assessing the ability of $A$. inulifolium to alter soil nutrient turnover through changes in quality and quantity of litter inputs, and decomposition rates. Two grassland communities were selected based on the extent of $A$. inulifolium invasion viz., less-invaded (LIG) and highly-invaded (HIG). The surface litter and standing litter biomass was quantified using randomly placed $1 \mathrm{~m}^{2}$ and $0.25 \mathrm{~m}^{2}$ quadrats, respectively. An in situ litterbag experiment was conducted using air-dried A. inulifolium and C. nardus litter separately and as a mixture to estimate decomposition rates and nutrient release patterns. The surface and standing litter biomass were significantly higher (at $\mathrm{p} \leq 0.001$ and $\leq 0.05$, respectively) in HIG than in LIG, with A. inulifolium contributing significantly (at $\mathrm{p} \leq 0.001$ ) to the standing litter biomass in both communities. A. inulifolium litter decayed and released nutrients rapidly than that of $C$. nardus. The findings of the study suggest that $A$. inulifolium invasion has the potential to increase the soil nutrient status through its high-nutrient litter inputs, rapid decomposition and nutrient release patterns. The results demonstrated the positive impact of $A$. inulifolium invasion on these nutrient-starved grasslands, while highlighting the potential role of invasive species in altering ecosystem functions, especially when they colonise degraded habitats.
\end{abstract}

Keywords: Decomposition, degraded grasslands, litter inputs, litter quality, nutrient release patterns, Sri Lanka.

\section{INTRODUCTION}

Inputs of plant litter and their quantity, quality and decomposition rates play key roles in maintaining soil fertility status and nutrient cycling processes in natural ecosystems (Berg et al., 2000; Wieder et al., 2009). Invasive plants generally produce more litter due to their rapid growth and release nutrients more quickly compared to native plants (Zhang et al., 2014), influencing not only the soil nutrients but also other properties such as soil moisture, microbiota and soil structure (Malinich et al., 2017). The mixing of litter of invasive plant species with that of native species may also modify litter dynamics in soil (Zhang et al., 2014).

Any change to plant communities that would occur following a single species becoming dominant alters the litter decomposition rates. Litter of different species belonging to different functional groups exert varying effects on soil properties (Zhang et al., 2014) through their ability to change the microenvironment including soil temperature (Parton et al., 2007), the decomposer community (Zhang et al., 2008), decomposition rates (Zhang et al., 2008; Shi et al., 2015) and competition for resources (Adair et al., 2008). The spread of invaders has the potential to alter soil moisture, temperature and niche availability over time, eventually influencing the decomposer communities (Bassett et al., 2010; Madawala, 2014). Some plant-specific factors such as high specific

\footnotetext{
*Corresponding author (ipkpiya52@gmail.com; (D https://orcid.org/0000-0003-1958-9508)
} 
leaf area, rapid growth rate, high productivity and elevated leaf nutrient concentrations are also considered as crucial factors in increasing the rate of decomposition and nutrient release pattern (Allison \& Vitousek, 2004). In addition, lignin content of plant litter, lignin:nitrogen ratio, carbon:nitrogen ratio, physical toughness and polyphenol content are also known contributing factors (Pe'rez-Harguindeguy et al., 2000; Coq et al., 2010). High quality litter (nutrient-rich litter) inputs together with rapid decomposition rates could affect the nutrient cycling process in an ecosystem (Kueffer et al., 2008; Chau et al., 2013). Since last decade, Austroeupatorium inulifolium (Kunth) R.M. King \& H. Rob. has been invading Cymbopogon nardus (L.) Rendle. dominated grasslands in the Central Highlands of Sri Lanka.

The Cymbopogon-dominated grasslands seem to show the highest vulnerability for this invasion compared to other land use types in the region. The present study quantified and compared the litter inputs, decomposition rates and nutrient-release patterns following invasion of Cymbopogon-dominated grasslands. The study hypothesised that $A$. inulifolium invasion shows the potential to alter the litter dynamics of Cymbopogondominated grasslands through increases in nutrient-rich litter inputs that decay and release nutrients faster than that of nutrient-poor Cymbopogon litter.

\section{METHODOLOGY}

\section{Study sites}

The study was carried out in C. nardus-dominated grasslands in the Knuckles Conservation Area (KCA) in the Wet Zone of Central Sri Lanka. The mean annual precipitation and temperature of the KCA were 2,725$4,470 \mathrm{~mm}$ and $21-25^{\circ} \mathrm{C}$, respectively. The grasslands were once tea plantations and later abandoned due to low productivity, approximately 30 years ago. With time, the abandoned tea plantations have been converted into highly degraded C. naruds-dominated grasslands. However, despite the ready availability of a rich seed source from nearby lower montane forest remnants, the grasslands remained as it is for the last few decades with no signs of natural regeneration. The lack of soil nutrients, high competition from the grass matrix and frequent fire incidences could have arrested its natural succession (Gunaratne et al., 2010).

Six representative sites (three from each) were randomly selected from two grassland communities; highly-invaded (HIG) and less-invaded (LIG) grasslands. LIG were dominated by C. nardus while the HIG were dominated by the invasive shrub, A. inulifolium. The HIG and LIG were categorised based on the stem density and plant cover (\%) values of $A$. inulifolium in respective sites. In HIG, the stem density was approximately 20 per $\mathrm{m}^{2}$ with a plant cover value of $>80 \%$, while in LIG the stem density was 7 per $\mathrm{m}^{2}$ with a plant cover value of $<30 \%$. The slope of the study sites varied from $20-40 \%$.

\section{Quantification of surface litter and standing litter}

Six plots representing two different habitat categories (HIG and LIG) were selected within an area of $6 \mathrm{~km}^{2}$. The surface litter was collected down to the mineral soil interface from two randomly placed $0.0625 \mathrm{~m}^{2}$ wooden quadrats per plot totaling 6 litter samples per habitat category. The litter samples were weighed after ovendried at $65^{\circ} \mathrm{C}$ to a constant weight. Standing litter was quantified using two randomly placed $0.25 \mathrm{~m}^{2}$ quadrats in each LIG and HIG plots. The vegetation was clipped to the ground level, and the clippings were dried at $65^{\circ} \mathrm{C}$ to a constant weight and weighed. The litter samples were sorted into Austroeupatorium and Cymbopogon to estimate their relative contributions towards the total standing litter biomass.

\section{In situ litter decomposition experiment}

An in situ litterbag experiment was conducted using recently senesced foliage of $A$. inulifolium and C. nardus to measure their decomposition rates and nutrient release patterns separately as well as in mixtures. Litterbags $\left(625 \mathrm{~cm}^{2}\right)$ were made out of $2 \mathrm{~mm}$ black nylon mesh material. Recently senesced foliage was collected from the field, air-dried, cut into $2.5 \mathrm{~cm}$ pieces and homogenised before adding $10 \mathrm{~g}$ into each litter bag (in litter mixtures, $5 \mathrm{~g}$ litter from each species). A total of 168 litterbags (56 each for A. inulifolium and C. nardus separately and 56 as a mixture of both species) were randomly distributed in LIG and HIG. The litter bags were placed in a manner that they had direct contact with the soil surface. From each habitat category (LIG and HIG), twelve litter bags ( 4 from each species and 4 from the mixture) were retrieved at regular time intervals, viz., $0,7,14,28,42,56,84,112,178$ days. The collected litter bags were weighed after oven-drying at $65{ }^{\circ} \mathrm{C}$ (for about $48 \mathrm{~h}$ ). Before oven-drying, the litter samples were cleaned manually to remove sand particles and other debris as much as possible. The litter samples at 178 days were not included in the analysis due to the lack of litter material. The litter samples were analysed for total carbon $(\mathrm{C})$, nitrogen $(\mathrm{N})$ and phosphorus $(\mathrm{P})$. Total carbon was measured using the wet oxidation method with potassium dichromate and total nitrogen using 
Kjeldahl technique. Total phosphorus was measured by a colourimetric method after the samples were digested in Kjeldahl oxidation (Anderson \& Ingram, 1993).

The mass loss of litter samples was estimated in terms of mass remaining (\%) with the help of equation (1).

Mass remaining $(\%)=\mathrm{M}_{\mathrm{t}} / \mathrm{M}_{0} \times 100$

where $\mathrm{M}_{0}=$ initial mass $(\mathrm{g})$ and $\mathrm{M}_{\mathrm{t}}=$ mass $(\mathrm{g})$ at time $\mathrm{t}$.

The decomposition rate constant $(\mathrm{k})$ was calculated from the decay curve using equation (2).

$\ln \left[\mathrm{M}_{0} / \mathrm{M}_{\mathrm{t}}\right]=\mathrm{k} \times \mathrm{t}$

where $\mathrm{M}_{0}=$ mass $(\mathrm{g})$ of litter at time 0 and $\mathrm{M}_{\mathrm{t}}=$ mass $(\mathrm{g})$ of litter at time t.

The percentage of nutrients remaining in decomposing litter (E) at different times of retrieval was also determined using equation (3).

$\mathrm{E}=\left[\mathrm{M}_{\mathrm{t}} \times \mathrm{C}_{\mathrm{t}} / \mathrm{M}_{0} \times \mathrm{C}_{0}\right] \times 100$

where, $\mathrm{M}_{0}$ is the initial mass $(\mathrm{g}), \mathrm{C}_{0}$ is the initial nutrient concentration $\left(\mathrm{mg} \mathrm{g}^{-1}\right), M_{t}$ is the oven-dry mass at time $t$ and $\mathrm{C}_{\mathrm{t}}$ is the nutrient concentration at time $\mathrm{t}$ (Zhao et al., 2013).

Descriptive statistics were carried out using Microsoft Excel version 10.1. All statistical analyses were performed using Minitab $^{\circledR}$ 17.1.0 statistical package. The level of significance for statistical tests was $\mathrm{p}<0.05$. Initial litter chemistry data (carbon, nitrogen, phosphorus and their respective ratios) were statistically analysed using one way ANOVA and mean separations were done using Tukey's family error rate. Repeated measures ANOVA was used to test the significant differences in litter mass remaining (\%) values in the litter bag experiment between different treatments (LIG/ $\mathrm{HIG}$ and Aus/Cym/Mix), where time is treated as a factor. Repeated measures ANOVA was also used to test the differences in mass loss and nutrient concentrations during the course of the incubation period. Species (Austroeupatorium/Cymbopogon), habitat (HIG and LIG) and time (incubation period) were considered as fixed factors. A test (Grubb's test at $5 \%$ level of significance) was performed to locate any outliers in the dataset. The outliers were removed before carrying out the statistical analyses. Mean separations for repeated measures ANOVA were also carried out using Tukey's family error rate.

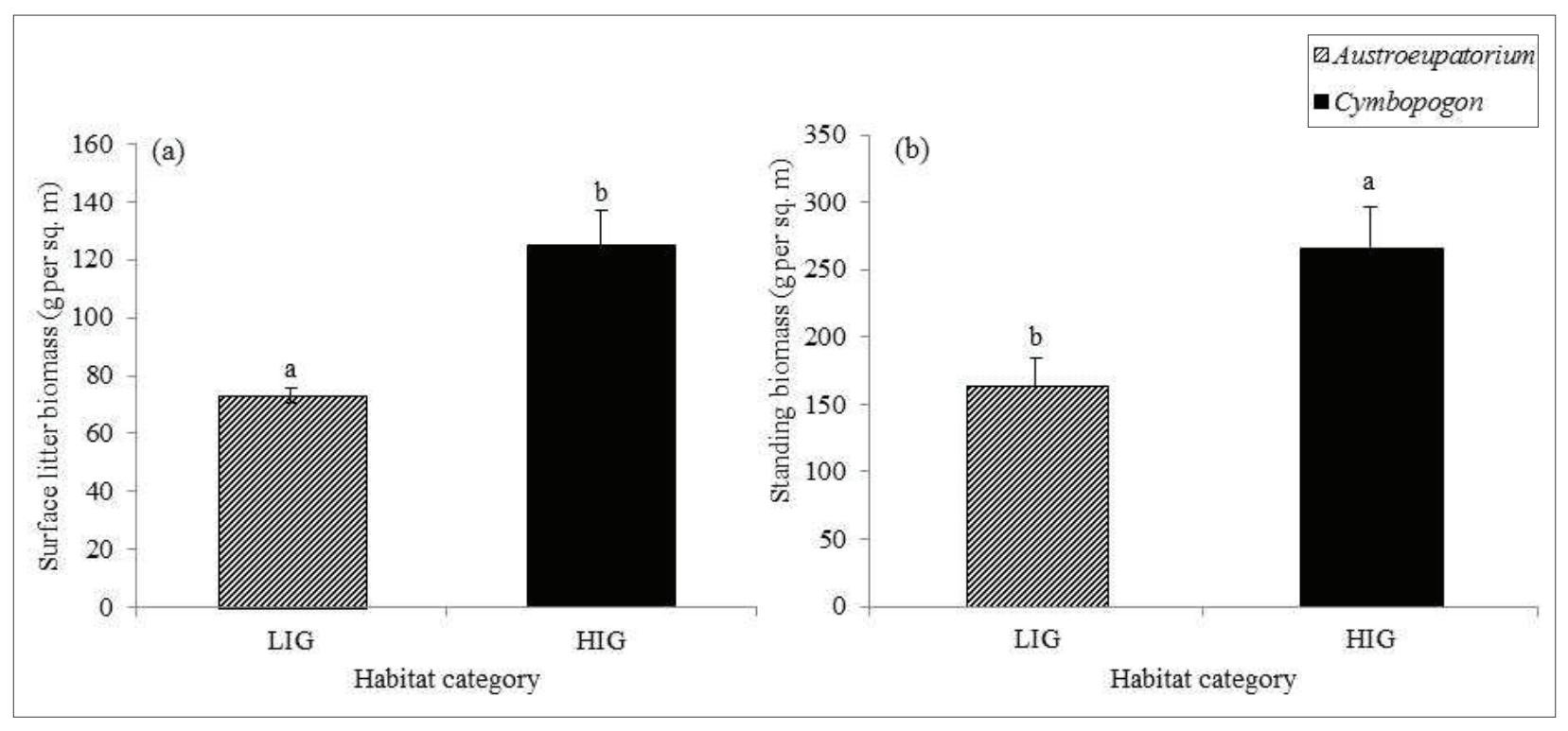

Figure 1: a) Surface litter biomass (g per sq. $\mathrm{m}$ ) and b) above ground total biomass (g per sq. $\mathrm{m}$ ) in less-invaded grassland (LIG) and highlyinvaded grassland $(\mathrm{HIG})$ habitats. Different letters indicate significant differences (surface litter biomass: ANOVA; F = 13.29, $\mathrm{p}=0.000$; above-ground total biomass: ANOVA; $\mathrm{F}=4.71, \mathrm{p}=0.037$ ). Vertical bars represent standard error of the mean $(\mathrm{SEM})$. 


\section{RESULTS AND DISCUSSION}

\section{Litter loading}

The surface and standing litter biomass were significantly higher in HIG than in LIG (surface litter biomass: ANOVA; $\mathrm{F}=13.29, \mathrm{p}=0.000$; total above ground biomass: ANOVA; $\mathrm{F}=4.71, \mathrm{p}=0.037$; Figure 1). A. inulifolium contributed significantly to the standing biomass in both habitats (75\% - HIG; $73 \%$ - LIG) compared to that of C. nardus (25\% - HIG; $26 \%$ - LIG) (Figure 2). Different plant traits show varying effects on their respective ecosystems (Hobbie et al., 2006; Knapp et al., 2008). The present findings show that A. inulifolium invasion contributed significantly to the litter loading in these grasslands, further proving the positive role of the invasive shrub. Litter accumulation in grasslands is more noticeable in areas with higher standing aboveground biomass (Wang \& Xu, 2012). A. inulifolium contributed significantly to the standing biomass and surface litter in both less- and highly-invaded areas of the grasslands. The rapid growth of $A$. inulifolium has significantly increased the litter inputs even in LIG where $C$. nardus dominates the vegetation. Higher litter inputs mean higher addition of nutrients to the soil. A recent study also reported a higher accumulation of litter in Californian grasslands invaded by Avena fatua and Elymus caput-medusae, suggesting long-term changes in litter dynamics (Mariotte et al., 2017). Not only the soil chemistry, but other microclimatic parameters including the reduction of sunlight reaching the ground level, increase in soil moisture and decrease in soil temperature fluctuations can be affected by the increase of high quality litter inputs following invasions (Wang \& Ruan, 2011; Montane et al., 2013; Warren et al., 2013; MedinaVillar et al., 2015). Such changes in the micro-habitat may sometimes affect the co-occurring native species negatively (Warren et al., 2013; Mariotte et al., 2017).

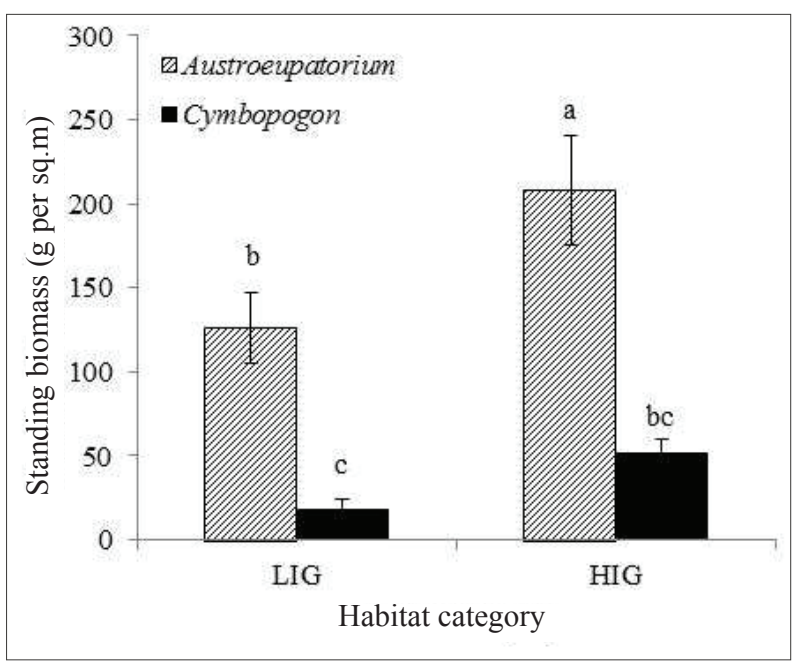

Figure 2: Average contribution of A. inulifolium and C. nardus plants (g per sq. $\mathrm{m}$ ) in less-invaded grassland (LIG) and highly-invaded grassland (HIG) habitats. Different letters indicate significant differences (GLM; $\mathrm{F}=41.38$, $\mathrm{p}=0.000)$. Vertical bars indicate standard error of mean (SEM) values.

\section{Litter quality}

The litter quality varied significantly between species and their mixtures (Table 1). Nitrogen was significantly higher in A. inulifolium and in litter mixtures (Austroeupatorium + Cymbopogon) compared to C. nardus only. C. nardus litter showed significantly higher $\mathrm{C}: \mathrm{N}$ and $\mathrm{C}: \mathrm{N}: \mathrm{P}$ ratios compared to other two litter types (A. inulifolium only and Austroeupatorium + Cymbopogon), with the lowest $\mathrm{C}: \mathrm{N}$ recorded in Austroeupatorium. Invasive plants are known to produce high quality litter than that of native species due to their rapid growth rates (Orwin et al., 2010). Previous studies have shown evidences to support that shrub invasions alter not only the existing

Table 1: The chemical composition ( \pm standard error of mean) and their respective ratios of A. inulifolium (Austro.), C. nardus (Cymbo.) and mixed litter (Austro + Cymbo) samples used in the in situ litter decomposition experiment. Different superscript letters indicate significant differences between species for each chemical parameter.

\begin{tabular}{lcccccc}
\hline Species & Total C $(\%)$ & Total N $(\%)$ & Total P $(\mu \mathrm{g} / \mathrm{g})$ & C:N & C:P & C:N:P \\
\hline A. inulifolium & $35 \pm 0.29^{\mathrm{b}}$ & $1.27 \pm 0.05^{\mathrm{a}}$ & $0.08 \pm 0.03^{\mathrm{a}}$ & $27 \pm 0.89^{\mathrm{c}}$ & $968 \pm 644^{\mathrm{a}}$ & $740 \pm 477^{\mathrm{b}}$ \\
C. nardus & $40 \pm 1.5^{\mathrm{ab}}$ & $0.33 \pm 0.07^{\mathrm{b}}$ & $0.05 \pm 0.01^{\mathrm{a}}$ & $141 \pm 40.8^{\mathrm{a}}$ & $864 \pm 34.3^{\mathrm{a}}$ & $3003 \pm 869^{\mathrm{a}}$ \\
Mixed litter & $45 \pm 3.32^{\mathrm{a}}$ & $1.14 \pm 0.06^{\mathrm{a}}$ & $0.09 \pm 0.00^{\mathrm{a}}$ & $39.3 \pm 1.08^{\mathrm{b}}$ & $497 \pm 32.6^{\mathrm{a}}$ & $436 \pm 13.9^{\mathrm{a}}$ \\
Level of significance & $* *$ & $* *$ & $\mathrm{~ns}$ & $*_{* *}$ & $\mathrm{~ns}$ & $* *$ \\
\hline
\end{tabular}

Significant differences are indicated as $\mathrm{p} \leq 0.001^{* * *}, \mathrm{p} \leq 0.01 * *, \mathrm{p} \leq 0.05^{*}$ and not significant, ns. 
vegetation in grasslands but also the edaphic properties and ecosystem functions (McLaren \& Turkington, 2011). The present study suggested that high inputs of quality litter following $A$. inulifolium invasion seems to alter the nutrient turnover rates in these highly-invaded grasslands. Montane et al. (2013) also noted that a shrub invasion has increased litter inputs in grasslands with the potential of altering the decomposition patterns through litter mixing.

\section{Litter decomposition rates}

In all litter types, litter decomposition was rapid initially and then followed by a much slower pace. However, $A$. inulifolium litter decomposed more rapidly throughout the incubation period than that of $C$. nardus, where the latter showed comparatively slow decay rates in both habitats with a $50 \%$ mass loss recorded after approximately 14 days (Figure 3 ). The present study has supported the fact that $A$. inulifolium invasion has the potential to influence the litter dynamics, thus the soil nutrient status may alter due to the increase in litter inputs and rapid decay in grasslands once dominated by C. nardus. However, the litter decomposition rates did not vary much between the two habitat categories. Litter decomposition is an important process in nutrient cycles that controls soil fertility, thus affecting the community composition and net primary production (Throop \& Archer, 2007). The results showed that A. inulifolium litter decomposed and released nutrients relatively faster than that of $C$. nardus. In support, previous studies have also shown that litter of invasive species decomposes faster than the native counterparts (Allison \& Vitousek, 2004; Blair \& Stowasser, 2009). Litter mixing events following invasions seem to alter the decay and nutrient release rates in ecosystems. The study also indicated that decay followed by nutrient release could be somewhat rapid in HIG than in LIG, suggesting perhaps a change of decomposer communities following shrub invasion. Previous studies have demonstrated that litter mixing may alter the microbial community, thus contributing positively in litter decomposition (Allison \& Vitousek, 2004; Ashton et al., 2005; Blair \& Stowasser, 2009; Chapman et al., 2013). The invasive species, Berberis thunbergii and Microstegium vimineum show the potential to alter soil microbial communities in forest soils (Kourtev et al., 1999). The leaf-related traits of invasive plants can play a major role in deciding the structure and functions of invaded communities (Goya et al., 2008; Godoy et al., 2010). A previous study carried out in the same grasslands at KCA noted an increase in the population of arbuscular mycorrhizal fungi (AMF) following the invasion of $A$. inulifolium (Madawala, 2014). Alteration of the soil microbial population and their functions may facilitate the growth of the invader over other co-occurring native species (Freschet et al., 2012; Karunaratne \& Madawala, 2016). Hence, invasive litter and their mixing ability seem to show the potential to alter the microbial composition and increase their functions, eventually contributing to high nutrient turnover in these highly invaded grasslands.

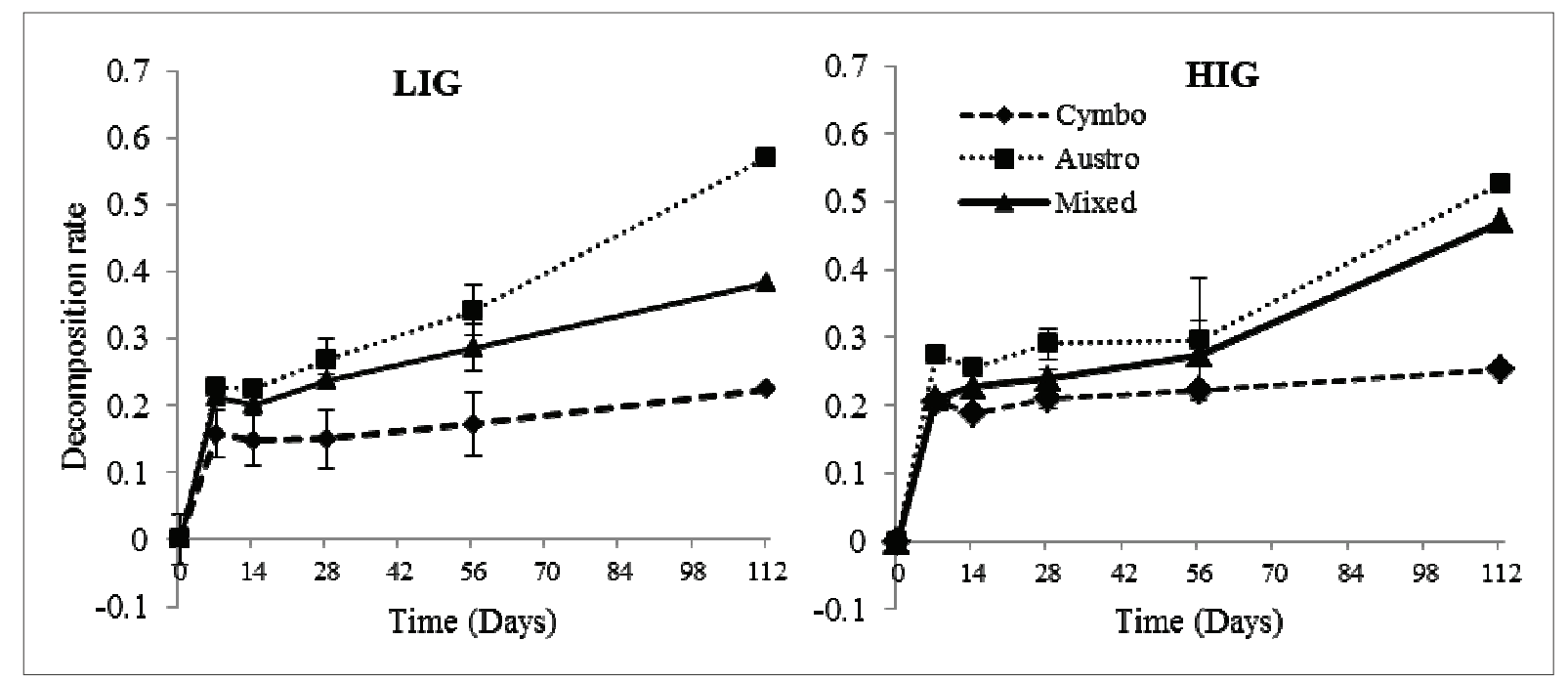

Figure 3: Decomposition rate (k) of A. inulifolium and C. nardus in a litter decomposition experiment under less-invaded grassland (LIG) and highly-invaded grassland (HIG) habitats. Vertical bars represent standard error of the mean (SEM). 


\section{Nutrient release patterns}

Repeated measures ANOVA indicated a significant interaction effect between the time and species (once nested within habitats) in litter samples and their mixtures (Table 2). When species nested in habitats, the remaining mass, $\mathrm{N}$ and $\mathrm{P}$ significantly differed among species. The results also showed that $A$. inulifolium litter released nutrients more rapidly compared to that of $C$. nardus. This rapid decay and subsequent release of nutrients can make a significant impact on these otherwise nutrient-starved grasslands (Gunaratne et al., 2010). Higher $\mathrm{N}$ content in litter may promote decomposition
(Cornwell et al., 2008). Edaphic properties in invaded habitats including higher levels of inorganic N (Kourtev et al., 1999; Mack et al., 2001) and higher rates of $\mathrm{N}$ mineralisation and nitrification (Evans et al., 2001; Mack et al., 2001) may involve in facilitating decomposition rates. The present study indicated that the release of $\mathrm{N}$ and $\mathrm{P}$ in $A$. inulifolium accelerates at the latter stage of the decaying process. Nitrogen and phosphorus in litter can accumulate during decomposition, hence providing nutrients for the decomposer communities. A. inulifolium leaf litter may consist of easily degradable organic compounds thereby releasing nutrients relatively rapidly than its co-occurring C. nardus.

Table 2: Repeated measures ANOVA results for A. inulifolium, C. nardus and their mixtures in two habitats [less-invaded (LIG) and highly-invaded grasslands (HIG)] after 112 days of in situ incubation period

\begin{tabular}{lccccccccc}
\hline & \multicolumn{3}{c}{ Mass remaining } & \multicolumn{3}{c}{ Remaining N } & \multicolumn{3}{c}{ Remaining P } \\
& df & $\mathrm{F}$ & $\mathrm{p}$ & $\mathrm{df}$ & $\mathrm{F}$ & $\mathrm{p}$ & $\mathrm{df}$ & $\mathrm{F}$ & $\mathrm{p}$ \\
\hline Habitat & 1 & 1.27 & $0.262^{\mathrm{ns}}$ & 1 & 3.71 & $0.057^{\mathrm{ns}}$ & 1 & 17.73 & $0.000^{* * *}$ \\
Species (Sp) & 2 & 8.28 & $0.000^{* * *}$ & 2 & 0.94 & $0.391^{\mathrm{ns}}$ & 2 & 0.46 & $0.635^{\mathrm{ns}}$ \\
Time (T) & 5 & 268 & $0.000^{* * *}$ & 5 & 7.18 & $0.000^{* * *}$ & 5 & 12.20 & $0.000^{* * *}$ \\
Sp (Habitat) & 4 & 57.82 & $0.000^{* * *}$ & 4 & 23.44 & $0.000^{* * *}$ & 4 & 13.9 & $0.000^{* * *}$ \\
Sp (Habitat)*T & 20 & 5.62 & $0.000^{* * *}$ & 20 & 2.98 & $0.000^{* * *}$ & 20 & 2.23 & $0.005^{* *}$ \\
\hline
\end{tabular}

Significant differences are indicated as $\mathrm{p} \leq 0.001^{* * *}, \mathrm{p} \leq 0.01^{* *}$ and $\mathrm{p} \leq 0.05^{*}$

Table 3: Decay rate (per days), mass and nutrients (nitrogen and phosphorus) remaining (as a percentage \pm standard error of mean) in leaf litter of A. inulifolium (Aus), C. nardus (Cym) and their mixture (Mix) in less-invaded grassland (LIG) and highly-invaded grassland (HIG) habitats after 112 days of in situ incubation period

\begin{tabular}{ccccccccc}
\hline & & Decay rate (per days) & Mass remaining & $\% \mathrm{~N}$ & $\% \mathrm{P}$ & $\mathrm{C}: \mathrm{N}$ & $\mathrm{C}: \mathrm{P}$ & $\mathrm{N}: \mathrm{P}$ \\
\hline \multirow{2}{*}{ Aus } & HIG & $0.27 \pm 0.03^{\mathrm{a}}$ & $54.2 \pm 4^{\mathrm{c}}$ & $90.1 \pm 10^{\mathrm{ab}}$ & $62.3 \pm 7^{\mathrm{a}}$ & $29.4 \pm 7^{\mathrm{bc}}$ & $36.3 \pm 6^{\mathrm{cd}}$ & $75.7 \pm 8^{\mathrm{bc}}$ \\
& LIG & $0.27 \pm 0.04^{\mathrm{a}}$ & $53.2 \pm 6^{\mathrm{c}}$ & $83.6 \pm 14^{\mathrm{b}}$ & $49.3 \pm 8^{\mathrm{c}}$ & $24.1 \pm 7^{\mathrm{c}}$ & $28.5 \pm 7^{\mathrm{d}}$ & $57.2 \pm 12^{\mathrm{c}}$ \\
& HIG & $0.18 \pm 0.02^{\mathrm{c}}$ & $71.5 \pm 3^{\mathrm{a}}$ & $55.5 \pm 6^{\mathrm{b}}$ & $69.5 \pm 7^{\mathrm{a}}$ & $60.9 \pm 8^{\mathrm{a}}$ & $52.8 \pm 6^{\mathrm{ab}}$ & $64.5 \pm 12^{\mathrm{c}}$ \\
& Mig & $0.14 \pm 0.02^{\mathrm{d}}$ & $73.8 \pm 6^{\mathrm{a}}$ & $96.6 \pm 14^{\mathrm{a}}$ & $49.3 \pm 7^{\mathrm{ab}}$ & $35.3 \pm 6^{\mathrm{bc}}$ & $64.6 \pm 6^{\mathrm{a}}$ & $139 \pm 21^{\mathrm{a}}$ \\
& HIG & $0.24 \pm 0.03^{\mathrm{b}}$ & $61.2 \pm 4^{\mathrm{b}}$ & $78.9 \pm 9^{\mathrm{ab}}$ & $61.4 \pm 8^{\mathrm{a}}$ & $39.7 \pm 6^{\mathrm{b}}$ & $47.5 \pm 7^{\mathrm{bc}}$ & $75.8 \pm 12^{\mathrm{bc}}$ \\
& LIG & $0.22 \pm 0.02^{\mathrm{b}}$ & $63.2 \pm 4^{\mathrm{b}}$ & $64.5 \pm 11^{\mathrm{b}}$ & $43.0 \pm 7^{\mathrm{bc}}$ & $54.3 \pm 7^{\mathrm{a}}$ & $65.7 \pm 9^{\mathrm{a}}$ & $95.4 \pm 14^{\mathrm{ab}}$ \\
\hline
\end{tabular}

Different superscript letters indicate significant differences between habitats. Values are given as mean percentage of dry weight $(n=4)$.

The nutrient release patterns of single-species litter samples (A. inulifolium and $C$. nardus) and their mixtures did not vary significantly among the habitats, LIG and HIG (Table 3; Figure 4). The elemental ratios of $\mathrm{C}: \mathrm{N}$ and $\mathrm{C}: \mathrm{P}$ in $A$. inulifolium litter have also shown a rapid decline over time than that of $C$. nardus and mixed litter with no differences between LIG and HIG
(Figure 5). The C:P ratio in C. nardus litter demonstrated a slower decline over time in both habitats compared to A. inulifolium and mixed-leaf litter. A relatively higher C content in $C$. nardus litter indicated a slower decay compared to other litter types. $C$. nardus also showed a relatively slow release of nutrients during decomposition compared to $A$. inulifolium. The nutrient release patterns 
of litter samples showed somewhat different trends between habitat types, but not significantly (Figure 4; Table 3). A. inulifolium showed a comparatively faster release of $\mathrm{C}$ compared to $C$. nardus and mixed litter, while $A$. inulifolium showed a rapid immobilisation of nutrients ( $\mathrm{P}$ and $\mathrm{N}$ ) with no noticeable differences

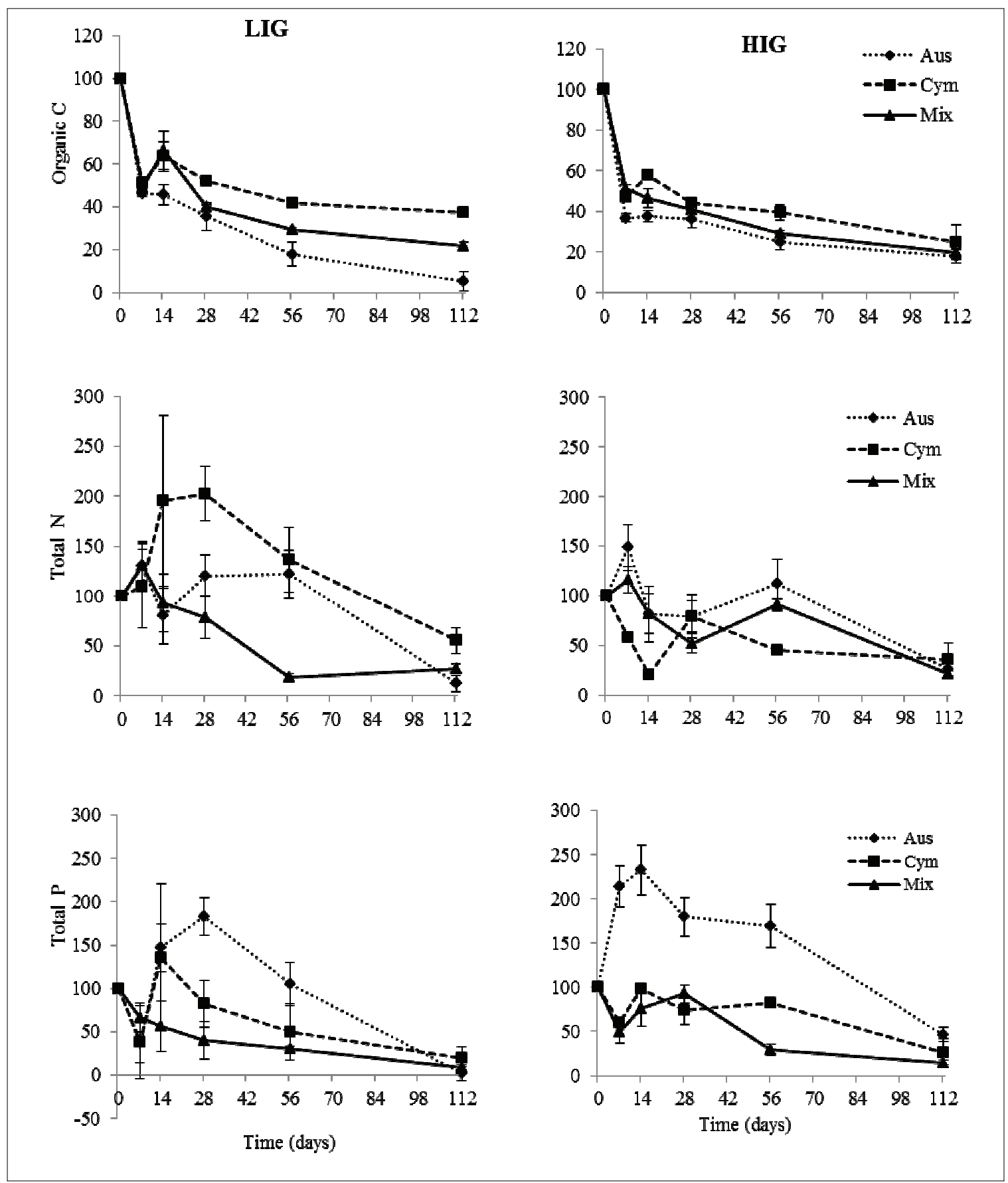

Figure 4: Remaining organic carbon (\%), nitrogen (\%) and phosphorus (\%) during the incubation period of litter decomposition study of A. inulifolium and C. nardus litter in less-invaded grassland (LIG) and highly-invaded grassland (HIG) habitats. Vertical bars represent standard error of the mean (SEM). 
between habitat categories (Figure 4). The decomposition rates of leaf litter are largely influenced by litter nutrient levels and their ratios (Karberg, 2008). The present study observed a rapid decline of nutrients and their ratios in A. inulifolium during the incubation period. The litter decomposition rates are positively correlated with the initial $\mathrm{N}$ concentrations of litter, and negatively with the initial C:N and C:P ratios (Karberg et al., 2008). During early stages of decomposition, the $\mathrm{C}: \mathrm{N}$ ratio can be the best predictor of mass loss and $\mathrm{N}$ release, while lignin
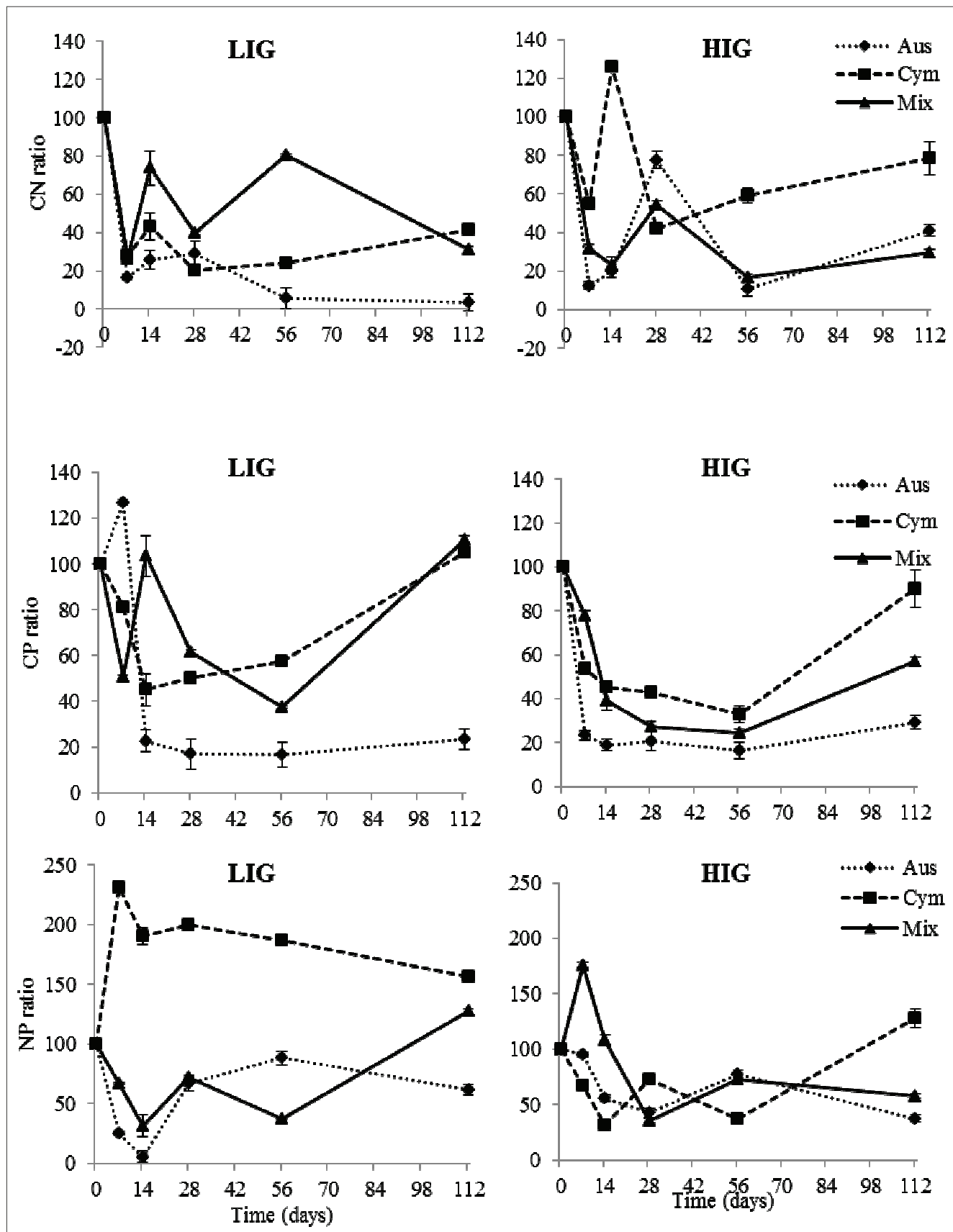

Figure 5: Remaining carbon:nitrogen $(\mathrm{C}: \mathrm{N})$, carbon:phosphorus $(\mathrm{C}: \mathrm{P})$ and nitrogen:phosphorus $(\mathrm{N}: \mathrm{P})$ ratios of A. inulifolium and C. nardus in litter decomposition experiment under less-invaded grassland (LIG) and highly-invaded grassland (HIG) habitats. Vertical bars represent standard error of the mean (SEM). 
becoming increasingly significant during the latter stages (Heal et al., 1997). In approval, the decomposition rate of $A$. inulifolium increased with the decreasing $\mathrm{C}: \mathrm{N}$ ratio. The reduction of $\mathrm{C}: \mathrm{N}$ ratios over time in both $A$. inulifolium and $C$. nardus suggested relatively rapid respiration and immobilisation of $\mathrm{N}$. Litter with low $\mathrm{C}: \mathrm{N}$ ratio, but relatively rich in $\mathrm{N}$, is readily degraded by fungi and bacteria than litter having higher $\mathrm{C}: \mathrm{N}$ ratios (Mack et al., 2001; Blair et al., 2009). The increases in nutrient contents observed during the initial stages of decomposition are possibly due to the immobilisation of nutrients by the microbes (Kourtev et al., 1998). Similar observations were also noted in the present study.

\section{CONCLUSIONS}

Austroeupatorium inulifolium invasion of grasslands previously dominated by Cymbopogon nardus has shown the potential to alter nutrient dynamics in these nutrient-starved man-made ecosystems. A. inulifolium litter has shown the ability to decompose and release nutrients faster than that of $C$. nardus. The invasion has also increased the nutrient-rich litter inputs significantly. Litter mixing following the invasion has also accelerated the decomposition rates and nutrient release patterns. The study concludes that $A$. inulifolium invasion has the potential to increase the soil fertility status in these degraded grassland communities over time. Enhanced edaphic properties together with improved microhabitat conditions may eventually trigger the arrested natural succession in these grasslands. The present study further supports the general notion that invasions can be productive when it occurs in nutrient-starved habitats.

\section{REFERENCES}

Adair E.C., Parton W.J., Del Grosso S.J., Silver W.L., Harmon M.E., Hall S.A., Burke I.C. \& Hart S.C. (2008). Simple three-pool model accurately describes patterns of long-term litter decomposition in diverse climates. Global Change Biology 14: 2636-2660.

DOI: https://doi.org/10.1111/j.1365-2486.2008.01674.x

Anderson J.M. \& Ingram J.S.I. (1993). Tropical Soil Biology and Fertility. A Handbook of Methods. CAB international, Wallingford, Oxon, UK.

Ashton I.W., Hyatt L.A., Howe K.M., Gurevitch J. \& Lerdau M.T. (2005). Invasive species accelerate decomposition and litter nitrogen loss in a mixed deciduous forest. Ecological Applications 15: 1263-1272. DOI: https://doi.org/10.1890/04-0741

Bassett I.E., Beggs J.R. \& Paynter Q. (2010). Decomposition dynamics of invasive alligator weed compared with native sedges in a Northland lake. New Zealand Journal of
Ecology 34(3): 324-331.

Berg B., Johansson M.B. \& Meentemeyer V. (2000). Litter decomposition in a transect of Norway spruce forests: substrate quality and climate control. Canadian Journal of Forestry Research 30: 1136-1147.

DOI: https://doi.org/10.1139/x00-044

Blair B.C. \& Stowasser A. (2009). Impact of Lonicera maackii on decomposition rates of native leaf litter in a southwestern Ohio woodland. Ohio Journal of Science 109(3): 43-47.

Chapman S.K., Newman G.S., Hart S.C., Schweitzer J.A. \& Koch G.W. (2013). Leaf litter mixtures alter microbial community development: mechanisms for non-additive effects in litter decomposition. Plos One 8(4): e62671. DOI: https://doi.org/10.1371/journal.pone.0062671

Chau M.M., Walker L.R. \& Mehltreter K. (2013). An invasive tree fern alters soil and plant nutrient dynamics in Hawaii. Bio Invasions 15: 355-370. DOI: https://doi.org/10.1007/s10530-012-0291-0

Coq S., Souquet J.M., Meudec E., Cheynier V. \& Hättenschwiler S. (2010). Interspecific variation in leaf-litter tannins drives decomposition in a tropical rainforest of French Guiana. Ecology 91: 2080-2091. DOI: https://doi.org/10.1890/09-1076.1

Evans R.D., Rimer R., Sperry L. \& Belnap J. (2001). Exotic plant invasion alters nitrogen dynamics in arid grassland. Ecological Applications 11(5): 1301-1310.

Freschet G.T., Aerts R. \& Cornelissen J.H.C. (2012). A plant economics spectrum of litter decomposability. Functional Ecology 26: 56-65.

DOI: https://doi.org/10.1111/j.1365-2435.2011.01913.x

Godoy O., Castro-Diez P., Logtestijn R.S.P. \& Cornelissen J.H.C. \& Valladares F. (2010). Leaf litter traits of invasive species slowdown decomposition compared to Spanish natives: a broad phylogenetic comparison. Oecologia 162: 781-790.

DOI: https://doi.org/10.1007/s00442-009-1512-9

Goya J.F., Frangi J.L., Pérez C. \& Tea F.D. (2008). Decomposition and nutrient release from leaf litter in Eucalyptus grandis plantations on three different soils in Entre Río. Bosque 29(3): 217-226.

Gunaratne A.M.T.A., Gunatilleke C.V.S., Gunatilleke I.A.U.N., Weerasinghe H.M.S.P.M. \& Burslem D.F.R.P. (2010). Barriers to tree seedling emergence on humaninduced grasslands in Sri Lanka. Journal of Applied Ecology 47(1): 157-165.

DOI: https://doi.org/10.1111/j.1365-2664.2009.01763.x

Heal O.W., Anderson J.M. \& Swift M.J. (1997). Plant litter quality and decomposition: an historical overview. In: Driven by Nature: Plant Litter Quality and Decomposition (eds. G. Cadish \& K.E. Giller). CAB International, Wallingford, UK.

Hobbie S.E., Reich P.B., Oleksyn J., Ogdahl M., Zytkowiak R., Hale C. \& Karolewski P. (2006). Tree species effects on decomposition and forest floor dynamics in a common garden. Ecology 87(9): 2288-2297.

Karberg N.J., Scott N.A. \& Giardina C.P. (2008). Methods for estimating litter decomposition. In: Field Measurements 
for Forest Carbon Monitoring (ed. C.M. Hoover), pp. 103111. Springer, New York, USA.

DOI: https://doi.org/10.1007/978-1-4020-8506-2_8

Karunaratne I. \& Madawala S. (2016). Austroeupatorium inulifolium invasion alters soil microbial populations to facilitate its own growth. Ceylon Journal of Science 45(3): 85-92.

DOI: https://doi.org/10.4038/cjs.v45i3.7404

Knapp S., Kühn I., Schweiger O. \& Klotz S. (2008). Challenging urban species diversity: contrasting phylogenetic patterns across plant functional groups in Germany. Ecology Letters 11: $1054-1064$.

DOI: https://doi.org/10.1111/j.1461-0248.2008.01217.x

Kourtev P.S., Ehrenfeld J.G. \& Huang W.Z. (1998). Effects of exotic plant species on soil properties in hardwood forests of New Jersey. Water Air Soil Pollution 105(1-2): 493-501.

DOI: https://doi.org/10.1023/A:1005037105499

Kourtev P.S., Huang W.Z. \& Ehrenfeld J.G. (1999). Differences in earthworm densities and nitrogen dynamics in soils under exotic and native plant species. Biological Invasions 1: $237-245$.

DOI: https://doi.org/10.1023/A:1010048909563

Kueffer C., Klingler G., Zirfass K., Schumacher E., Edwards P. \& Güsewell S. (2008). Invasive trees show only weak potential to impact nutrient dynamics in phosphorus-poor tropical forests in the Seychelles. Functional Ecology 22: 359-366.

DOI: https://doi.org/10.1111/j.1365-2435.2007.01373.x

Mack M.C., Dantonio C.M. \& Ley R.E. (2001). Alteration of ecosystem nitrogen dynamics by exotic plants: a case study of C-4 grasses in Hawaii. Ecological Applications 11: $1323-1335$.

DOI: https://doi.org/10.2307/3060923

Madawala H.M.S.P. (2014). Austroeupatorium inulifolium invasion increases arbuscular mycorrhizal abundance in Cymbopogon-dominated grasslands in Knuckles Conservation Area. Journal of the National Foundation of Sri Lanka 42(4): 361-364.

DOI: https://doi.org/10.4038/jnsfsr.v42i4.7735

Malinich E., Lynn-Bell N. \& Kourtev P.S. (2017). The effect of the invasive Elaeagnus umbellate on soil microbial communities depends on proximity of soils to plants. Ecosphere 8(5): Article ID e01827.10.1002. DOI: https://doi.org/10.1002/ecs2.1827

Mariotte P., Spotswood E.N., Farrer E.C. \& Suding K.N. (2017). Positive litter feedbacks of an introduced species reduce native diversity and promote invasion in Californian grasslands. Applied Vegetation Science 20: 28-39. DOI: https://doi.org/10.1111/avsc.12291

McLaren J.R. \& Turkington R. (2011). Biomass compensation and plant responses to 7 years of plant functional group removals. Journal of Vegetation Science 22: 503-515. DOI: https://doi.org/10.1111/j.1654-1103.2011.01263.x

McLaren J.R. \& Turkington R. (2010). Ecosystem properties determined by plant functional group identity. Journal of Ecology 98: 459-469. DOI: https://doi.org/10.1111/j.1365-2745.2009.01630.x
Medina-Villar S., Castro-Díez P., Alonso A. \& Cabra-Rivas I. (2015). Do the invasive trees, Ailanthus altissima and Robinia pseudoacacia, alter litterfall dynamics and soil properties of riparian ecosystems in Central Spain? Plant Ecology 396(1-2): 311-324.

Montané F., Romanyà J., Rovira P. \& Casals P. (2013). Mixtures with grass litter may hasten shrub litter decomposition after shrub encroachment into mountain grasslands. Plant and Soil 368(1-2): 459-469.

DOI: https://doi.org/10.1007/s11104-012-1533-8

Orwin K.H., Buckland S.M., Johnson D., Turner B.L., Smart S., Oakley S. \& Bardgett R.D. (2010). Linkages of plant traits to soil properties and the functioning of temperate grassland. Journal of Ecology 98:1074-1083.

DOI: https://doi.org/10.1111/j.1365-2745.2010.01679.x

Pérez-Harguindeguy N., Diaz S., Cornelissen J.H.C., Vendramini F., Cabido M. \& Castellanos A. (2000). Chemistry and toughness predict leaf litter decomposition rates over a wide spectrum of functional types and taxa in central Argentina. Plant and Soil 218: 21-30.

DOI: https://doi.org/10.1023/A:1014981715532

Shi L., Fan S., Jiang Z., Qi L. \& Liu G. (2015). Mixed leaf litter decomposition and N, P release with a focus on Phyllostachys edulis (Carrière) J. Houz. forest in subtropical South Eastern China. Acta Societatis Botanicorum Poloniae 84(2): 207-214.

DOI: https://doi.org/10.5586/asbp.2015.019

Throop H.L. \& Archer S.R. (2007). Interrelationships among shrub encroachment, land management, and litter decomposition in a semi-desert grassland. Ecological Applications 17: 1809-1823.

DOI: https://doi.org/10.1890/06-0889.1

Wang S.J. \& Ruan H.H. (2011). Effects of soil mesofauna and microclimate on nitrogen dynamics in leaf litter decomposition along an elevation gradient. African Journal of Biotechnology 10: 6732-6742.

Wang Z. \& Xu W. (2013). Decomposition-rate estimation of leaf litter in karst forests in China based on a mathematical model. Plant Soil 367(1-2): 563-577.

DOI: https://doi.org/10.1007/s11104-012-1479-x

Warren R.J., Bahn V. \& Bradford M.A. (2013). Decoupling litter barrier and soil moisture influences on the establishment of an invasive grass. Plant and Soil 367(1-2): 339-346.

DOI: https://doi.org/10.1007/s11104-012-1477-z

Wieder W.R., Cleveland C. \& Townsend A.R. (2009). Controls over leaf litter decomposition in wet tropical forests. Ecology 90(12): 3333-3341.

DOI: https://doi.org/10.1890/08-2294.1

Zhang D., Hui D., Luo Y. \& Zhou G. (2008). Rates of litter decomposition in terrestrial ecosystems: global patterns and controlling factors. Journal of Plant Ecology 1(2): 85-93. DOI: https://doi.org/10.1093/jpe/rtn002

Zhang L., Wang H., Zou J., Rogers W.E. \& Siemann E. (2014). Non-native plant litter enhances soil carbon dioxide emissions in invaded annual grassland. PLOS ONE 9: Article ID e92301.

DOI: https://doi.org/10.1371/journal.pone.0092301 
Zhao L., Hu Y.L., Lin G.G., Gao Y.C., Fang Y.T. \& Zeng D.H. (2013). Mixing effects of understory plant litter on decomposition and nutrient release of tree litter in two plantations in northeast China. PLOS ONE 8(10): Article ID e76334.

DOI: https://doi.org/10.1371/journal.pone.0076334 